\title{
Temperature and Precipitation Extremes in the United States: Quantifying the Responses to Anthropogenic Aerosols and Greenhouse Gases ${ }^{\mathscr{O}}{ }^{+}+$
}

\author{
Nora R. MAscioli AND ARlene M. Fiore \\ Department of Earth and Environmental Sciences, and Lamont-Doherty Earth Observatory, \\ Columbia University, Palisades, New York \\ Michael Previdi AND Gustavo CorRea \\ Lamont-Doherty Earth Observatory, Columbia University, Palisades, New York
}

(Manuscript received 10 July 2015, in final form 5 November 2015)

\begin{abstract}
Changes in extreme temperatures, heat waves, and heavy rainfall events have adverse effects on human health, air quality, and water resources. With aerosol-only (AER) and greenhouse gas-only (GHG) simulations from 1860 to 2005 in the GFDL CM3 chemistry-climate model, aerosol-induced versus greenhouse gas-induced changes in temperature (summer) and precipitation (all seasons) extremes over the United States are investigated. Small changes in these extremes in the all forcing simulations reflect cancellations between the effects of increasing anthropogenic aerosols and greenhouse gases. In AER, extreme high temperatures and the number of days with temperatures above the 90th percentile decline over most of the United States. The strongest response occurs in the western United States $\left(-2.0^{\circ} \mathrm{C}\right.$ and -14 days, regionally averaged) and the weakest response occurs in the southeastern United States $\left(-0.6^{\circ} \mathrm{C}\right.$ and -4.8 days $)$. An opposite-signed response pattern occurs in GHG $\left(+2.3^{\circ} \mathrm{C}\right.$ and +11.5 days over the western United States and $+1.6^{\circ} \mathrm{C}$ and +7.2 days over the southeastern United States). The similar spatial response patterns in AER versus GHG suggest a preferred regional mode of response that is largely independent of the type of forcing. Extreme precipitation over the eastern United States decreases in AER, particularly in winter, and increases over the eastern and central United States in GHG, particularly in spring. Over the twenty-first century under the representative concentration pathway 8.5 (RCP8.5) emissions scenario, the patterns of extreme temperature and precipitation associated with greenhouse gas forcing dominate.
\end{abstract}

\section{Introduction}

Observations in the United States indicate increases over recent decades in extreme high temperatures, heat waves, and heavy rainfall events, with far-reaching implications for human health, agriculture, air quality, water management, and economic growth (Kunkel et al. 2008). The number of unusually hot days per year has risen $2 \%-3 \%$ over the United States since 1950, with the

\footnotetext{
Supplemental information related to this paper is available at the Journals Online website: http://dx.doi.org/10.1175/JCLI-D-150478.s1.

${ }^{+}$Lamont-Doherty Publication Number 7954.

Corresponding author address: Nora R. Mascioli, 206A Oceanography, 61 Route 9W, P.O. Box 1000, Palisades, NY 10964-8000. E-mail: mascioli@ldeo.columbia.edu
}

most significant increases occurring in the western United States (Peterson et al. 2008; Portmann et al. 2009). The number of heat waves has also increased significantly since 1960 , as has the area of the United States experiencing unusually hot daily high temperatures (Kunkel et al. 2008). Over the twentieth century, U.S. extreme precipitation events have increased in frequency and intensity, particularly over the central United States (e.g., Karl and Knight 1998; Groisman et al. 2005; Kunkel et al. 2008). The amount of precipitation occurring on the heaviest precipitation days has increased more rapidly than the total precipitation (Groisman et al. 2004). Additionally, the area of the United States influenced annually by extreme precipitation events ( $>50 \mathrm{~mm}$ ) increased significantly from $9 \%$ to $11 \%$ over the twentieth century (Karl and Knight 1998).

These observed changes in climate extremes have adverse impacts on human health and the economy. 
Summer heat waves have been shown to increase mortality by $2 \%-5 \%$; approximately 1000 deaths per year can be attributed to these events in the United States (Anderson and Bell 2011; Changnon et al. 1996). Furthermore, extreme temperatures and heat waves have also been shown to correlate with extreme air pollution events (e.g. Logan 1989; Tai et al. 2010, 2012; Leung and Gustafson 2005). Heavy storms can incur property damage and threaten human life (Lott and Ross 2006), including through major flood events and flash floods (Kunkel et al. 2013). Studies have shown that extreme precipitation contributes to the spread of disease in the United States (Engelthaler et al. 1999; Glass et al. 2000; Curriero et al. 2001). Taken together, extreme heat and precipitation events cost the United States billions of dollars in damages each year (Lott and Ross 2006).

Natural and manmade systems are generally adapted to the current range of extreme events. Therefore, changes in the frequency, magnitude, and duration of these events pose significant challenges and risks (Kunkel et al. 2008). Models from phase 5 of the Coupled Model Intercomparison Project (CMIP5) show increases at the end of the twenty-first century relative to 1901-60 in U.S. monthly mean summer temperatures of $5^{\circ}-7^{\circ} \mathrm{C}$ (Maloney et al. 2014). Similarly, U.S. maximum summer temperatures are projected to increase by $5^{\circ}-7^{\circ} \mathrm{C}$ relative to $1981-2000$ (Sillmann et al. 2013b). Under the SRES A1B future scenario, heat waves in the United States continue to increase in both duration and frequency over the twenty-first century over the Great Plains region, the Pacific Northwest, the Northeast, and the Southeast (Lau and Nath 2012). Following representative concentration pathway 8.5 (RCP8.5), CMIP5 models project increases by the end of the twenty-first century, relative to $1901-60$, in mean winter precipitation over most of the United States, with the largest increases $\left(0.5-1.0 \mathrm{~mm} \mathrm{day}^{-1}\right)$ occurring in the Northeast and the Northwest (Maloney et al. 2014). Annually, CMIP5 models project significant increases of $5 \%-15 \%$ relative to $1981-2000$ in total precipitation in the northern United States (Sillmann et al. 2013b). The contribution to the total annual precipitation coming from days with extremely high rainfall is projected to increase by $20 \%-40 \%$ over the central United States and $40 \%-70 \%$ over the eastern and western United States (Sillmann et al. 2013b).

There remains a considerable amount of uncertainty in our understanding of past climate and projections for the future, which derives partly from uncertainty in the effects of atmospheric aerosols, which typically cool the climate, both directly and via interactions with clouds (Boucher et al. 2013). Aerosols are short-lived in the atmosphere and their emissions from anthropogenic sources are projected to decline over the next century. It is therefore important to understand how they are affecting the present climate in order to accurately project the effects of their removal. Here, we use a set of "single forcing" experiments performed by a state-of-the-art general circulation model (GCM) to investigate the historical changes in extreme temperature and precipitation in the United States in response to anthropogenic forcing. These single-forcing simulations allow us to individually assess the effects of anthropogenic aerosols and greenhouse gases, revealing patterns of change not visible in the full historical simulations due to cross-cancellations.

Section 2 describes the model simulations and defines the extreme indices that we examine. In section 3 , we discuss the modeled changes in U.S. extreme heat and precipitation as a result of increasing aerosols and greenhouse gases over the historical period (1860-2005). Section 4 projects future twenty-first-century changes in extremes under the RCP8.5 scenario, in which greenhouse gas concentrations increase while aerosol emissions decrease. Finally, conclusions are presented in section 5 .

\section{Methods}

\section{a. Model description, simulations, and significance testing}

We use the GFDL CM3 chemistry-climate model to evaluate changes in extreme temperature and precipitation over the United States induced by changes in aerosol and greenhouse gas burdens. CM3 simulations use a cubed sphere grid with 48 vertical levels; archived fields are regridded to a $2^{\circ} \times 2.5^{\circ}$ latitude-longitude grid. In addition to its atmospheric component (AM3), CM3 includes the Modular Ocean Model (MOM), a land component with dynamic vegetation (LM3), and a sea ice model, described in Donner et al. (2011). Of key importance for our study is the inclusion in AM3 of a more complex aerosol scheme, relative to earlier versions of the model, in which prognostic aerosols interact with clouds, as well as interactive tropospheric and stratospheric chemistry (Horowitz 2006; Ming et al. 2006, 2007; Naik et al. 2013). Aerosol concentrations are calculated from the Atmospheric Chemistry and Climate Model Intercomparison Project (ACCMIP) historical (Lamarque et al. 2010) and RCP8.5 future (van Vuuren et al. 2011) emissions inventories, and undergo atmospheric transport, chemical transformations, and wet and dry deposition. AM3 accounts for anthropogenic and biomass burning emissions of aerosols and aerosol precursors, including sulfur dioxide, black 
carbon, and organic carbon (Lamarque et al. 2010) and volcanic emissions of sulfur dioxide (Dentener et al. 2006). The model includes a simple representation of secondary organic aerosol production, including natural sources from plants (Dentener et al. 2006) and anthropogenic sources from the oxidation of butane (Tie et al. 2005). Dimethyl sulfide (DMS; a sulfate precursor) emissions from seawater (Chin et al. 2002), dust (Ginoux et al. 2001), sea salt (Monahan et al. 1986), and secondary organic aerosol production from sea spray (O'Dowd et al. 2008) respond to meteorology and thus changes in climate.

In AM3, prognostic aerosols alter cloud properties by acting as cloud condensation nuclei. This affects the size distribution of droplets in the cloud, producing clouds with smaller droplets, which reflect more incoming solar radiation (cloud albedo effect; Twomey 1977). In addition, smaller droplets are lighter and so are less likely to precipitate out of the cloud, increasing its lifetime (cloud lifetime effect; Albrecht 1989). Both of these indirect effects of aerosols on clouds will tend to reduce incoming solar radiation, cooling the climate (Boucher et al. 2013). In the model, aerosol indirect effects occur only in liquid clouds; cloud droplet activation depends on the type of aerosol (sulfate, organic carbon, and sea salt), its size distribution (assumed separately for each aerosol species), and updraft velocities within shallow cumulus and stratiform clouds (Donner et al. 2011; Golaz et al. 2013). Monthly mean cloud droplet sizes in AM3 have been compared with satellite retrievals (MODIS) and found to match many of the observed features such as enhancement in cloud droplet sizes off the east coasts of continents (Donner et al. 2011). Model-simulated droplet sizes, however, are generally biased low (Donner et al.2011), although the MODIS retrievals of cloud droplet sizes are uncertain and generally larger than other satellite-based estimates (Han et al. 1994).

As part of CMIP5, a number of simulations were designed to explore key regions of uncertainty in the climate system, for example forcing due to anthropogenic aerosols (Taylor et al. 2012). We use daily surface air temperature and precipitation data from five of the simulations designed for CMIP5: the aerosol-only simulations, with anthropogenic aerosols as the only time-varying forcing and all other forcings held at preindustrial levels (AER); greenhouse gas-only simulations, with anthropogenic greenhouse gases as the only time-varying forcing $(\mathrm{GHG})$; the full historical simulations (HIST), with all natural and anthropogenic forcings (including land-use changes) varying in time; a future emissions scenario (RCP8.5), in which greenhouse gases increase from 2006 through 2100 while anthropogenic aerosols decrease (Riahi et al. 2011); and an $800-y r$ preindustrial control run. Additionally, we analyze a modified future scenario in which greenhouse gases follow their trajectory from RCP8.5, while aerosol concentrations are held constant at 2005 levels (RCP8.5_2005Aer; Westervelt et al. 2015). The AER, GHG, RCP8.5, and RCP8.5_2005Aer simulations each consist of three ensemble members, differing only in their initial conditions; HIST has five ensemble members; and the preindustrial control run consists of a single ensemble member. The AER, GHG, and HIST simulations are run from 1860 through 2005.

We consider the ensemble mean changes in each CM3 simulation. The statistical significance of these changes is assessed using two methods. In the first method, we use a $z$ test to determine where the difference between 30-yr means is statistically different from zero ( $95 \%$ confidence). In the second method, the 800-yr control run is split into distinct 30-yr segments. We then construct a probability density function for the difference between the means of two randomly selected 30-yr segments. Differences in the forced simulations that fall outside the $95 \%$ confidence interval of this distribution are considered to be outside the range of modeled internal variability.

\section{b. Extreme indices}

The extreme climate indices defined by the Expert Team on Climate Change Detection and Indices (ETCCDI; Sillmann et al. 2013a,b) serve as the basis for our analysis, with a focus on two temperature indices (TXx and TX90p) and two precipitation indices (PRCPTOT and R99p). TXx is the maximum of the maximum daily temperature over a given time period. TX90p represents the number of days with a maximum temperature above the 90th percentile. The 90th percentile threshold in a given grid cell on calendar day $i$ is defined by constructing the probability distribution of daily maximum temperature during days $i-2$ through $i+2$ over a 30 -yr base period. PRCPTOT is the total precipitation over a given time period. R99p, representing extreme precipitation, is the total amount of precipitation occurring on days with precipitation values above the 99th percentile of the climatology. For the two threshold-based indices, TX90p and R99p, we use 196190 as the climatological base period in each simulation. We focus primarily on summertime TXX and TX90p and winter and spring PRCPTOT and R99p. Further details about these indices are provided in Sillmann et al. (2013a,b).

\section{c. Model evaluation}

CM3 captures the observed global climatology from 1981 to 2000 in the two metrics for extreme temperature as determined from the ERA-40, ERA-Interim, NCEP-1, and NCEP-2 reanalyses (Sillmann et al. 2013a). CM3 


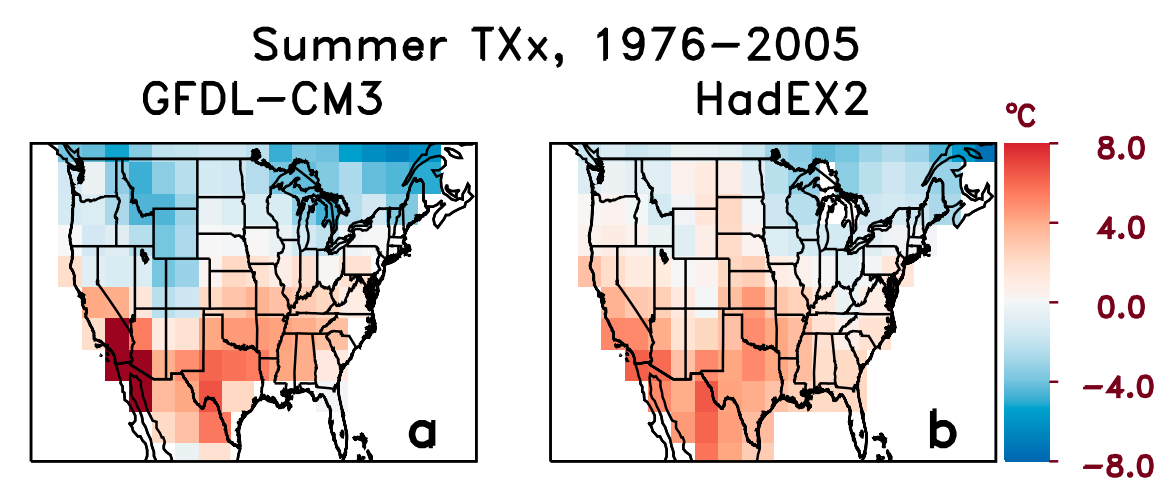

FIG. 1. Spatial anomalies of 1976-2005 summer TXx relative to the U.S. mean of $31.6^{\circ}$ and $35.4^{\circ} \mathrm{C}$ in $\mathrm{CM} 3$ and $\mathrm{HadEX} 2$, respectively in (a) the $\mathrm{CM} 3$ historical simulation and (b) observations (HadEX2). The pattern correlation coefficient $r$ is 0.51 .

summertime mean temperatures are biased cold $\left(-2.24^{\circ} \mathrm{C}\right)$, distributed evenly over the continental United States, with respect to CRU observations from 1979 to 2005 (Donner et al. 2011; Sheffield et al. 2013). The summer cold bias is likely due to a "cloud lifetime effect" (aerosol second indirect effect) that is too strong in the model (Ackerman et al. 2004; Quaas et al. 2009; Guo et al. 2011; Golaz et al. 2013; Levy et al. 2013). Despite the bias, the model roughly captures the spatial distribution of observed summertime temperatures: both the monthly mean (Sheffield et al. 2013) and TXx (Fig. 1). The observed TXx data are from the Hadley Centre Global Extreme Index 2 (HadEX2; Donat et al. 2013a,b).

Comparing the simulated number of days per season with at least $20-\mathrm{mm}$ precipitation $(\mathrm{R} 20 \mathrm{~mm})$ with observations from the Global Precipitation Climatology Project (GPCP; Huffman et al. 2001, 2015) and the Tropical Rainfall Measuring Mission (TRMM; TRMM Project 2015) shows that the model is able to capture both the magnitude and spatial distribution of this index in winter and spring (Fig. 2). CM3 exceeds observed seasonal mean precipitation over much of North America in winter in comparison to the 1979-2005 climatology from GPCP (Sheffield et al. 2013); this effect is most pronounced over western North America $(+52.7 \%$ of the observed mean $)$ and much smaller over eastern North America ( $+4.46 \%$ of observed mean). Sheffield et al. (2013) also find a small low bias in mean precipitation over central North America in winter $(-2.6 \%$ of the observed mean). Despite these biases, CM3 generally captures the observed spatial distribution of wintertime precipitation (Sheffield et al. 2013). In summer, CM3 captures observed mean precipitation over eastern (bias of $-4.38 \%$ ) and central North America (bias of $+7.45 \%$ ), but is biased high over western North America ( $+54.74 \%$ of the observed mean; Sheffield et al. 2013). The model does not capture the observed spatial distribution of U.S. summertime precipitation, a common weakness among CMIP5 models, most likely due to a failure to represent the dynamical conditions that produce summertime precipitation (see Fig. S1 in the supplemental material; Sheffield et al. 2013; G. Vecchi, personal communication, 10 April 2015).

\section{Historical changes over the United States: Greenhouse gases versus aerosols}

\section{a. Temperature extremes}

In this section we examine summertime changes in TX90p and TXx, which provide information on changes in the magnitude and frequency of extreme high temperatures, using the AER, GHG, and HIST simulations (section 2a). Significant changes in summertime TX90p occur in AER and GHG between 1860-89 and 19762005 (Figs. 3a,b). Increases in atmospheric aerosols generally lead to decreases in TX90p while rising greenhouse gases generally lead to increases. Increasing greenhouse gases produce warming outside of the range of modeled internal variability everywhere in the United States, whereas increasing aerosols produce cooling outside of this range over most of the United States, with the exception of the Southeast. Changes in the historical simulations, from 1860 to 2005 , are generally not statistically significantly outside the range of internal variability as determined from the preindustrial control simulation (Fig. 3c). As discussed in section 2c, the forcing in AER is most likely too strong, resulting in the absence of a significant temperature response in HIST. However, the CM3 representation of observed spatial distributions of mean and extreme temperatures provides confidence that the model is useful for analysis of the spatial patterns of response to aerosol and greenhouse gas forcing. 


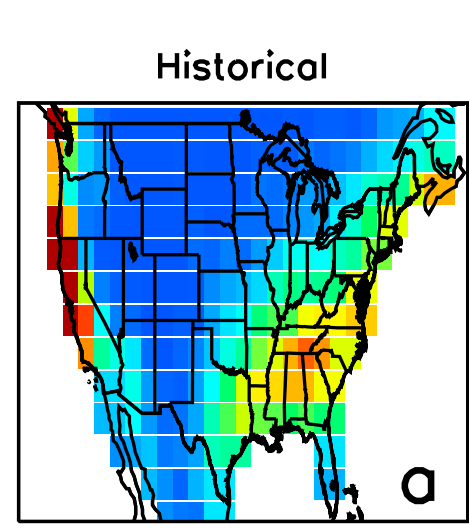

R20mm, DJF 1998-2015
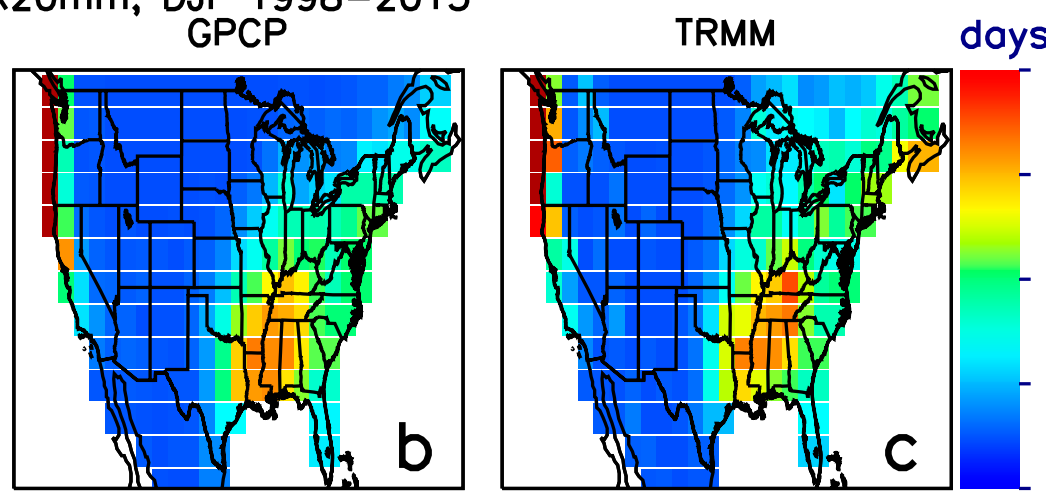

Historical

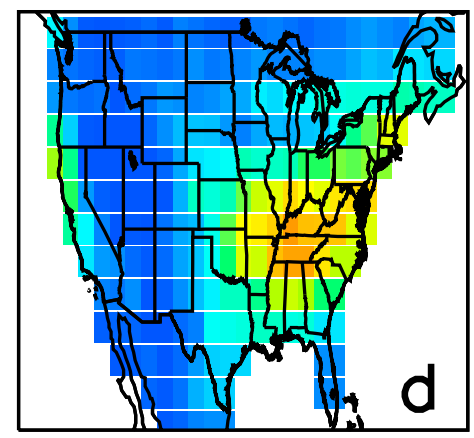

R20mm, MAM 1998-2015 GPCP

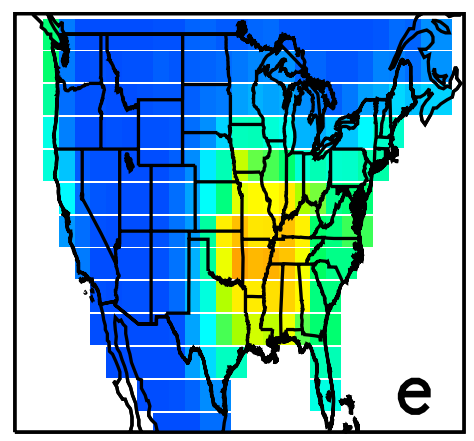

TRMM

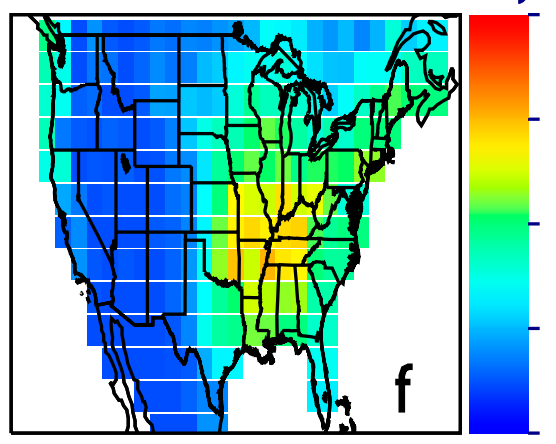

FIG. 2. Average number of days per season (1998-2015) with at least $20 \mathrm{~mm}$ of precipitation (R20mm) in (a),(d) the CM3 historical simulation and observations from (b),(e) GPCP and (c),(f) TRMM in (top) winter [December-February (DJF)] and (bottom) spring [March-May (MAM)]. The pattern correlation coefficients between CM3 and GPCP are 0.83 (winter) and 0.85 (spring). The pattern correlation coefficients between CM3 and TRMM are 0.78 (winter) and 0.85 (spring). The pattern correlations between GPCP and TRMM are 0.91 (winter) and 0.89 (spring). The historical simulation has been extended to 2015 using RCP8.5.

Anthropogenic greenhouse gases are generally longlived and thus well mixed in the atmosphere, while aerosols have a heterogeneous spatial distribution. However, Figs. $3 \mathrm{a}$ and $3 \mathrm{~b}$ show a statistically significant spatial anticorrelation between the response patterns associated with greenhouse gases and aerosols over the United States $(r=-0.72)$. In both AER and GHG the largest temperature changes occur in the western United States $(-14.0$ and +11.5 days respectively), with relatively weaker changes in the Northeast $(-9.6$ and +10.9 days) and little to no statistically significant change in the Southeast $(-4.8$ and +7.2 days). This response pattern is consistent with observations showing a relative intensification of warming in the western United States in comparison with the eastern United States over the twentieth century (Meehl et al. 2012; Donat et al. 2013a). Because of the similarity in spatial response pattern and magnitude between GHG and AER, there is a cancellation between these two competing effects in the all forcing simulation, resulting in little to no change in TX90p in Fig. 3c, although we note that the aerosol forcing is likely too strong.

TXx similarly shows a significant anticorrelation between the effects of greenhouse gases and aerosols, with a pattern correlation coefficient of -0.64 (Figs. 3d,e). The largest responses to anthropogenic forcing occur in the western United States, where aerosols reduce TXx by $-2.0^{\circ} \mathrm{C}$ and greenhouse gases increase TXx by $2.3^{\circ} \mathrm{C}$. The response in the Southeast is relatively weak, with aerosols reducing $\mathrm{TXx}$ by $-0.6^{\circ} \mathrm{C}$ (not statistically significant at the $95 \%$ confidence level) and greenhouse gases increasing TXx by $1.6^{\circ} \mathrm{C}$. Cancellations between the effects of aerosols and greenhouse gases on TXx result in relatively small changes in the historical simulation (Fig. 3f).

The lack of statistically significant cooling in the Southeast in the aerosol-only simulations and collocated warming minimum in the greenhouse gas-only simulations are of particular interest because observations of 

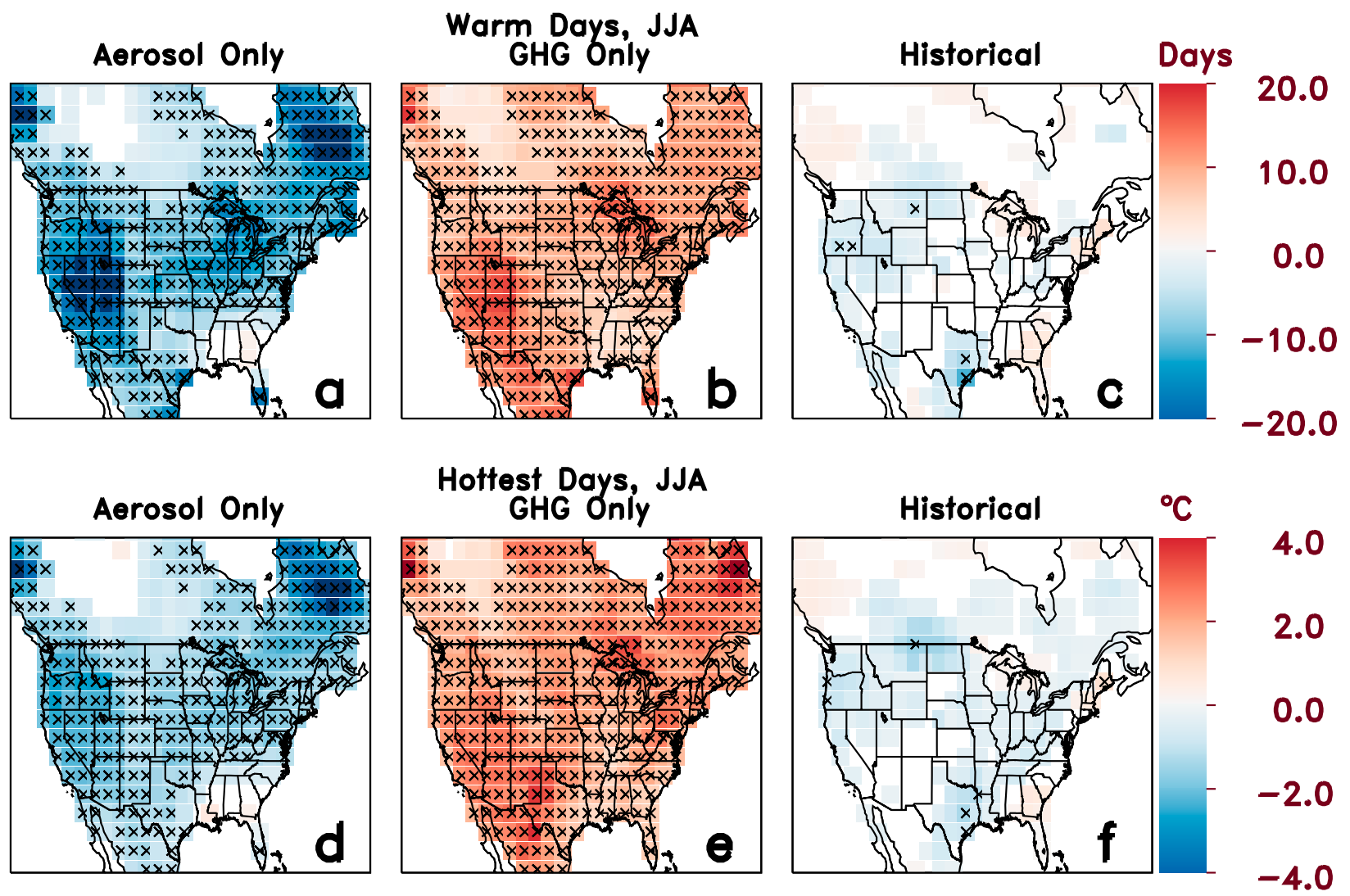

FIG. 3. Changes in the 30-yr ensemble mean values of summer [June-August (JJA)] (top) TX90p and (bottom) TXx between the beginning (1860-89) and end (1976-2005) of the (a),(d) aerosol-only, (b),(e) greenhouse gas-only, and (c),(f) historical simulations. Ocean regions and grid cells where the change is not significantly different from zero ( $95 \%$ confidence) are whited out. The crosses denote that the changes are outside of the range of natural variability ( $95 \%$ confidence), as determined from the model's preindustrial control simulation and described in section 2 .

both mean and extreme temperature in this region show a cooling trend from 1901-2012, referred to as the "warming hole" (e.g., Hartmann et al. 2013; Donat et al. 2013a). Previous studies focusing on the warming hole have identified several potential natural and anthropogenic causes of this feature, such as changes in local hydroclimate (e.g., Pan et al. 2004; Weaver 2013; Portmann et al. 2009), changes in sea surface temperature forcing from the Pacific and Atlantic (Meehl et al. 2012; Weaver 2013), cooling induced by aerosol forcing (Leibensperger et al. 2012; Yu et al. 2014), and land use change (Misra et al. 2012). In the GFDL CM3 model, one of the few CMIP5 models that captures the warming hole (Pan et al. 2013; Kumar et al. 2013), the persistence of a muted temperature response in the Southeast over multiple decades, and across multiple ensemble members and different forcing scenarios, suggests a characteristic response to radiative forcing in this model, rather than internal variability or cooling due to anthropogenic aerosols. Further analysis of this feature is beyond the scope of this paper.

\section{b. Precipitation extremes}

Overall, aerosols tend to reduce precipitation in the United States while greenhouse gases tend to increase it (Fig. 4; see Fig. S2 in the supplemental material). However, the spatial distribution of changes in precipitation varies by season and type of forcing. This finding is consistent with previous modeling studies that found that the precipitation response pattern is dependent on the type of forcing agent and its spatial distribution (e.g., Kloster et al. 2010; Shindell et al. 2012). Wintertime extreme precipitation (R99p) in the eastern United States increases significantly in GHG $(18 \mathrm{~mm}$ in the Southeast and $7.2 \mathrm{~mm}$ in the Northeast) and decreases significantly in AER $(-14 \mathrm{~mm}$ in the Southeast and $-4.5 \mathrm{~mm}$ in the Northeast; Figs. 4a,b). Changes elsewhere in the United States are not significant in winter. Changes in R99p in AER and GHG are spatially anticorrelated in winter $(r=-0.62)$. In the 


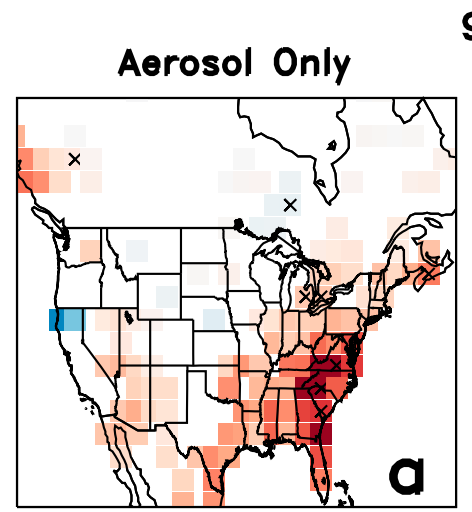

99th Percentile Rain, DJF
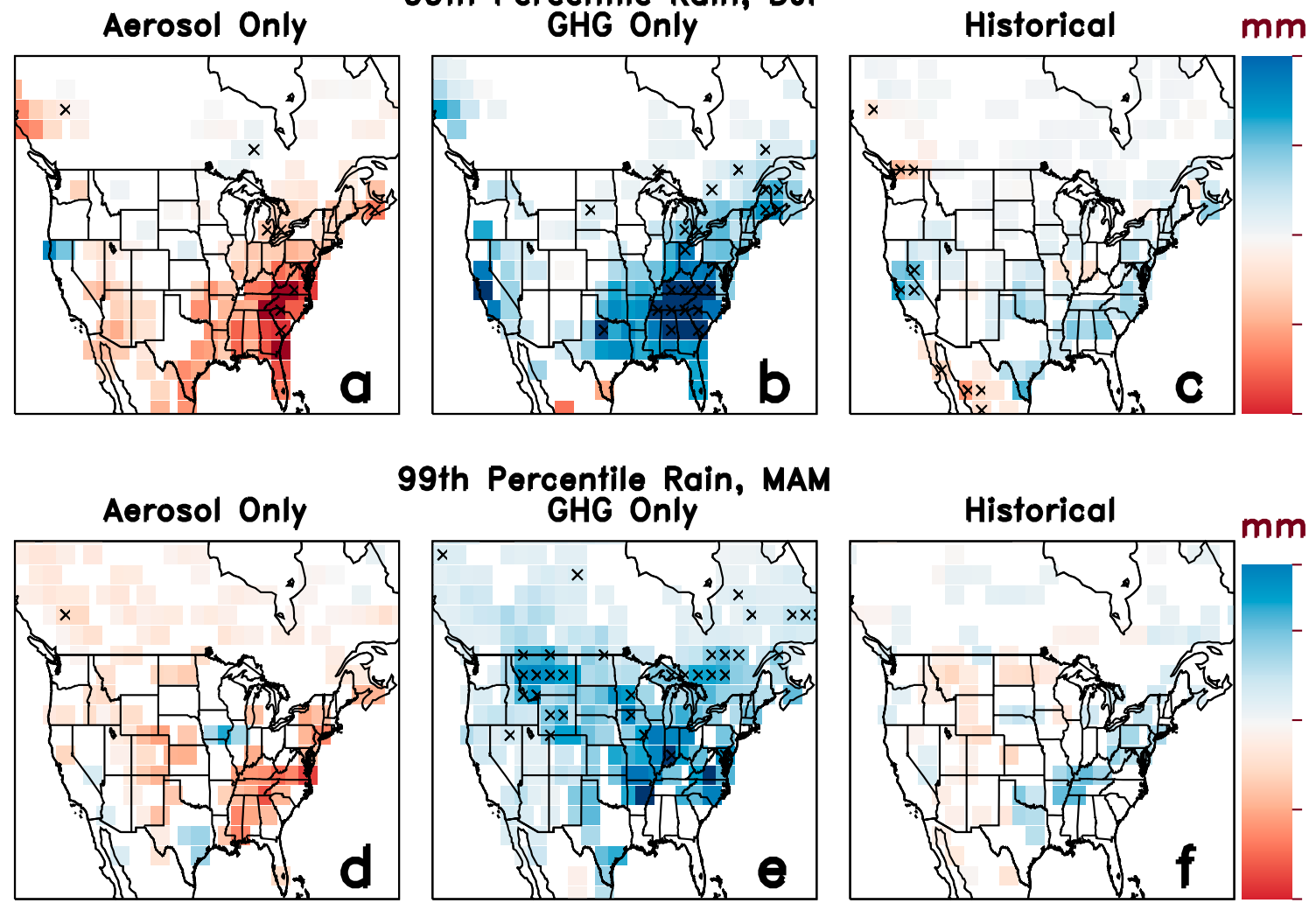

99th Percentile Rain, MAM
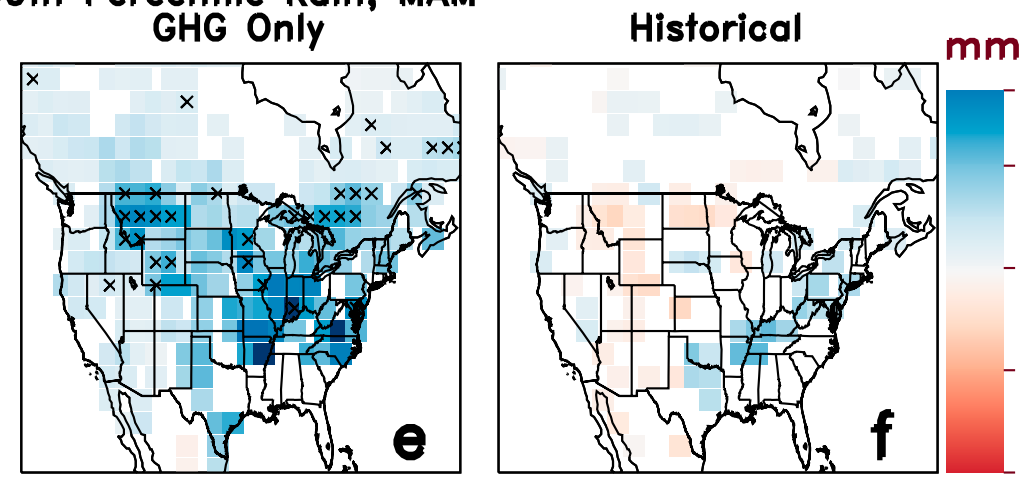

FIG. 4. Changes in the 30-yr ensemble mean values of R99p between the beginning (1860-89) and end (1976-2005) of the (a),(d) aerosol-only, (b),(e) greenhouse gas-only, and (c),(f) historical scenarios in (top) winter and (bottom) spring. Statistical significance testing is as in Fig. 3.

spring, extreme precipitation in AER decreases slightly in the eastern United States, but it is not significant (Fig. 4d). However, in GHG, springtime extreme precipitation increases over most of the central and eastern United States (Fig. 4e). In this season, the anticorrelation between AER and GHG is weak $(r=-0.24)$, suggesting that different mechanisms determine the springtime impacts of aerosols and greenhouse gases on extreme precipitation. Changes in HIST are shown for both seasons for completeness, but are not significant due to cancellations between the effects of aerosols and greenhouse gases (Figs. 4c,f). Changes in extreme precipitation in summer and fall are less significant than those in winter and spring and are shown in Fig. S3 of the supplemental material.

\section{Future changes in U.S. temperature and precipitation extremes}

\section{a. Extreme temperatures become the new normal}

Under the RCP8.5 scenario, in which anthropogenic radiative forcing reaches approximately $8.5 \mathrm{~W} \mathrm{~m}^{-2}$ by
2100 (relative to the preindustrial values), well-mixed greenhouse gases increase steadily throughout the twenty-first century, while emissions of short-lived pollutants (aerosols, and aerosol and tropospheric ozone precursors) decrease dramatically due to air quality regulations (Riahi et al. 2011). By midcentury, the warming signal associated with the combined effects of increasing greenhouse gas concentrations and decreasing aerosol concentrations is apparent over the United States, with increases in TX90p on the order of 40-50 days per summer (Figs. 5a,b) and increases in TXx between $2.5^{\circ}$ and $6.0^{\circ} \mathrm{C}$ (Figs. $5 \mathrm{c}, \mathrm{d}$ ). The combined effects of increasing greenhouse gases and removing the masking by anthropogenic aerosols produce much larger changes than in either HIST or in the observed changes over the historical period (Donat et al. 2013a; Sillmann et al. 2013a). The large increase in TX90p in the Southeast at the start of the twenty-first century is a consequence of the shape of the temperature distribution in the region and does not indicate rapid warming. By the end of the twenty-first century, TX90p saturates with respect to the 1961-90 climatology and almost all 

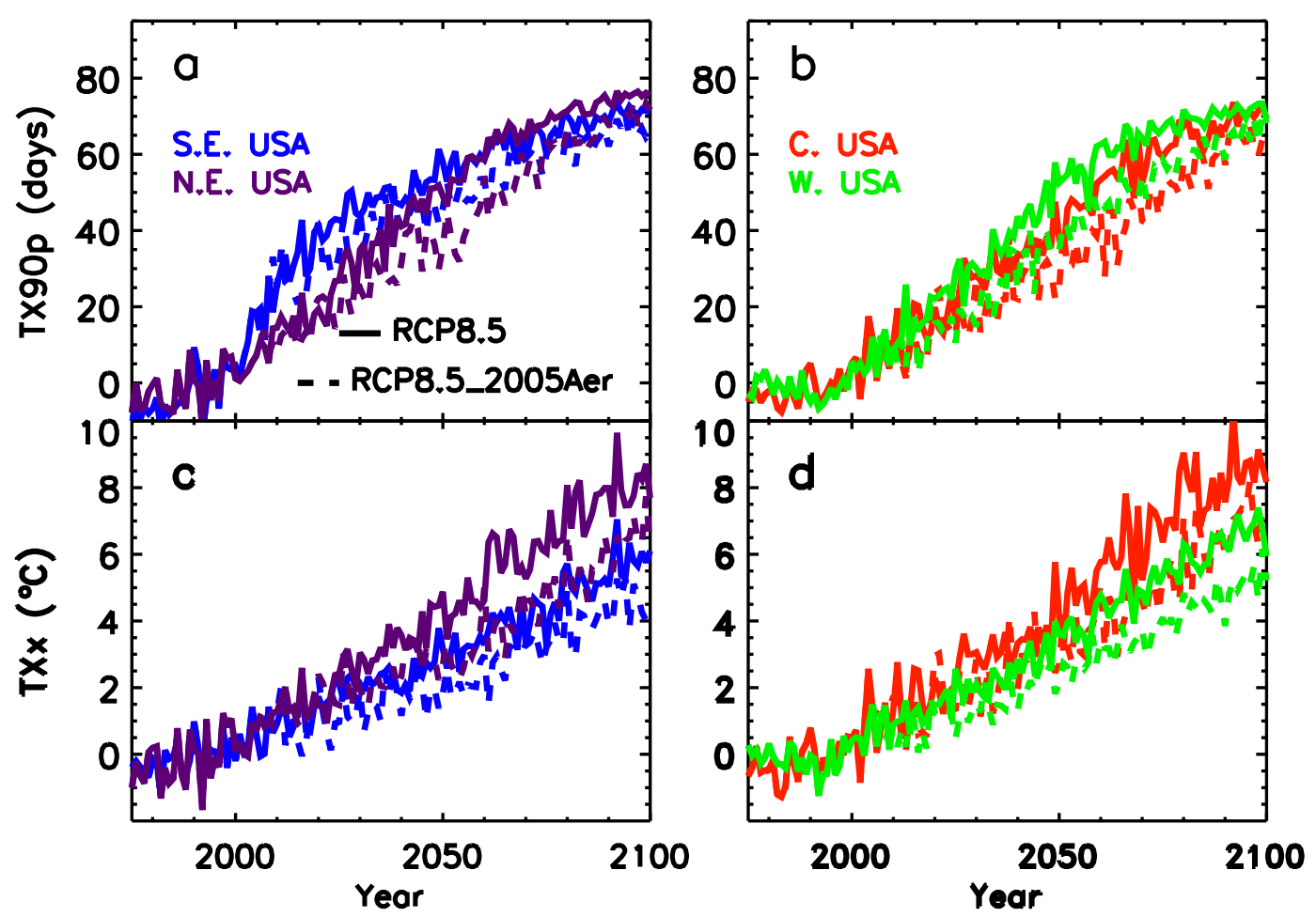

FIG. 5. Summertime (a),(b) TX90p and (c),(d) TXx for RCP8.5 (solid lines) and RCP8.5_2005Aer (dashed lines) for different U.S. regions, expressed as anomalies with respect to 1976-2005. The tapering off in TX90p at the end of the twenty-first century is an artifact of the index becoming saturated with respect to the 1961-90 thresholds.

summer days lie above the 90th percentile thresholds. TXx also increases substantially by $5^{\circ}-10^{\circ} \mathrm{C}$ across the United States. These results are consistent with projected increases in monthly mean temperature over the United States of $6^{\circ} \pm 3^{\circ} \mathrm{C}$ in the CMIP5 multimodel mean (Maloney et al. 2014). For both TX90p and TXx, the spatial pattern of the temperature response in the twenty-first century is similar to the GHG simulation (Figs. 3b,e and Figs. S3 and S4 in the supplemental material). Significant warming occurs everywhere by midcentury, although the Southeast warms more slowly than the rest of the country.

We investigate next how long it will take before future anthropogenic climate change can be expected to exceed the range of modeled internal variability (which does not occur in HIST due to cancellation between aerosols and greenhouse gases). We define the time of emergence as the first year when the difference between the 30-yr mean centered on that year and the end of the twentieth century (1976-2005) is outside of the range of variability in the preindustrial control simulation at the 95\% confidence level (following the approach described previously). For both TX90p and TXx, the climate change signal becomes detectable within the first few decades of the twenty-first century over most of the
United States (Figs. 6a,b). In some regions, such as the West and the Northeast, the signal has emerged within 15 years of the reference period (1976-2005), consistent with the rapid increases shown in Fig. 5.

To separate the effects of decreasing aerosol concentrations and increasing greenhouse gas concentrations, we examine a second future scenario, RCP8.5 2005Aer, in which greenhouse gas concentrations follow the RCP8.5 trajectory while aerosols are held constant at 2005 levels. The dashed lines in Fig. 5 show that holding aerosols constant reduces future increases in TX90p and TXx relative to RCP8.5. By midcentury, TX90p is reduced by an average of 15 days per summer in the eastern United States, and by an average of 10 days per summer in the central and western United States. (RCP8.5 - RCP8.5_2005Aer). By the end of the twenty-first century, TX90p is reduced by an average of 10 days per summer over the continental United States, although even with aerosols held constant at 2005 levels, the index is approaching saturation. Similarly, the continued presence of aerosols at 2005 levels reduces midcentury increases in TXx by $1.5^{\circ} \mathrm{C}$ over the eastern United States and $1.0^{\circ} \mathrm{C}$ over the central and western United States. By the end of the century increases in TXx are reduced by $1.5^{\circ} \mathrm{C}\left(\mathrm{RCP} 8.5-\mathrm{RCP} 8.5 \_2005 \mathrm{Aer}\right)$ 


\section{Warm Days, JJA RCP 8.5}

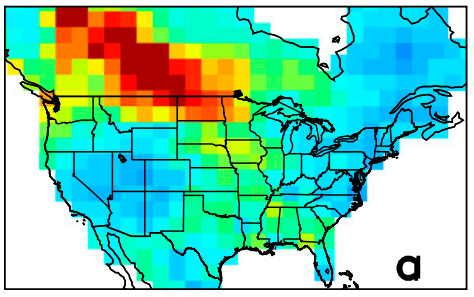

RCP 8.5 2005Aer

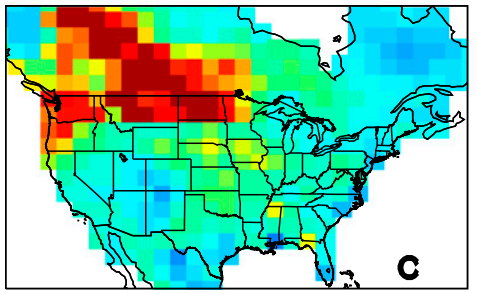

Hottest Days, JJA RCP 8.5
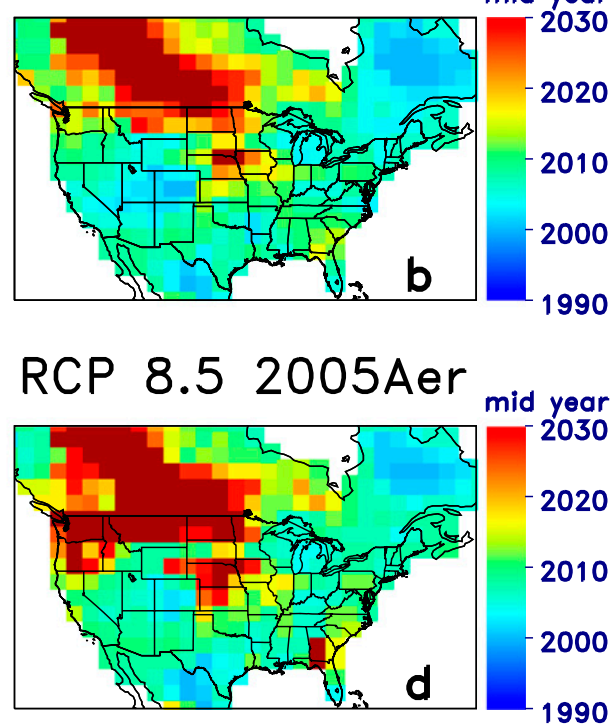

FIG. 6. Time of emergence for changes in 30-yr mean (a),(c) TX90p and (b),(d) TXx relative to the present day (1976-2005) for the (top) RCP8.5 and (bottom) RCP8.5_2005Aer scenarios. Colors indicate the midpoint of the earliest 30 -yr period for which the difference is outside the range of natural variability between 30 -yr periods within the preindustrial control run (see section 2).

in the Southeast, and $1.75^{\circ} \mathrm{C}$ in the rest of the United States on average.

Even with aerosols held constant at 2005 levels, statistically significant increases in extreme temperatures still occur over the continental United States due to rising greenhouse gases. By midcentury, TX90p increases by 25-35 days per summer across most of the United States, and by 55-65 days per summer by the end of the century (RCP8.5_2005Aer), when more than twothirds of the summer days are above the 1961-90 90th percentile threshold. TXx increases by $2.5^{\circ}-3.5^{\circ} \mathrm{C}$ by midcentury, and by $5^{\circ}-6^{\circ} \mathrm{C}$ by the end of century, reflecting the dominant influence of greenhouse gases. For both indices, the time of emergence (Figs. 6c,d) is delayed by at most five years over most of the United States when aerosols are maintained at 2005 levels.

\section{b. Extreme precipitation: Shifting toward a wetter future}

Future changes in extreme precipitation also show patterns associated with the greenhouse gas signal evident from the 1860-2005 GHG simulation. By the end of the twenty-first century, wintertime R99p has increased significantly over the eastern and northwestern United States (Fig. S6 in the supplemental material). In the Southeast and the Northeast, R99p increases by 32 and
$42 \mathrm{~mm}$ respectively (Fig. 7a), whereas it increases in the western United States by $18 \mathrm{~mm}$ (Fig. 7b). In spring, R99p increases significantly over the eastern and northcentral United States (Figs. 7c,d and S6). By the end of the twenty-first century, springtime R99p has increased by $30 \mathrm{~mm}$ in the Southeast, and by $40 \mathrm{~mm}$ in the Northeast (Fig. 7c). On average, comparing 2070-99 to 1976-2005, springtime R99p increases by $9.5 \mathrm{~mm}$ in the central U.S. (Fig. 7d), but with a region in the northcentral United States that increases by $30 \mathrm{~mm}$ (Fig. S6d). Summertime changes in extreme precipitation are generally not significant (Fig. S6). Finally, in fall, there are statistically significant increases in R99p in the Northeast and the Northwest, averaging 25 and $15 \mathrm{~mm}$ respectively by the end of the century (Figs. 7e,f and S6). In contrast with winter and spring, there are generally no statistically significant changes in total precipitation in this season (Fig. S7 in the supplemental material), indicating a change in the shape of the overall distribution of precipitation, with a tendency toward more extreme precipitation.

The climate change signal is slower to emerge for precipitation than for temperature. The changes emerge as significant early in the twenty-first century in the eastern United States in winter and spring (Figs. 8a,b); in the western United States in winter, the signal emerges 

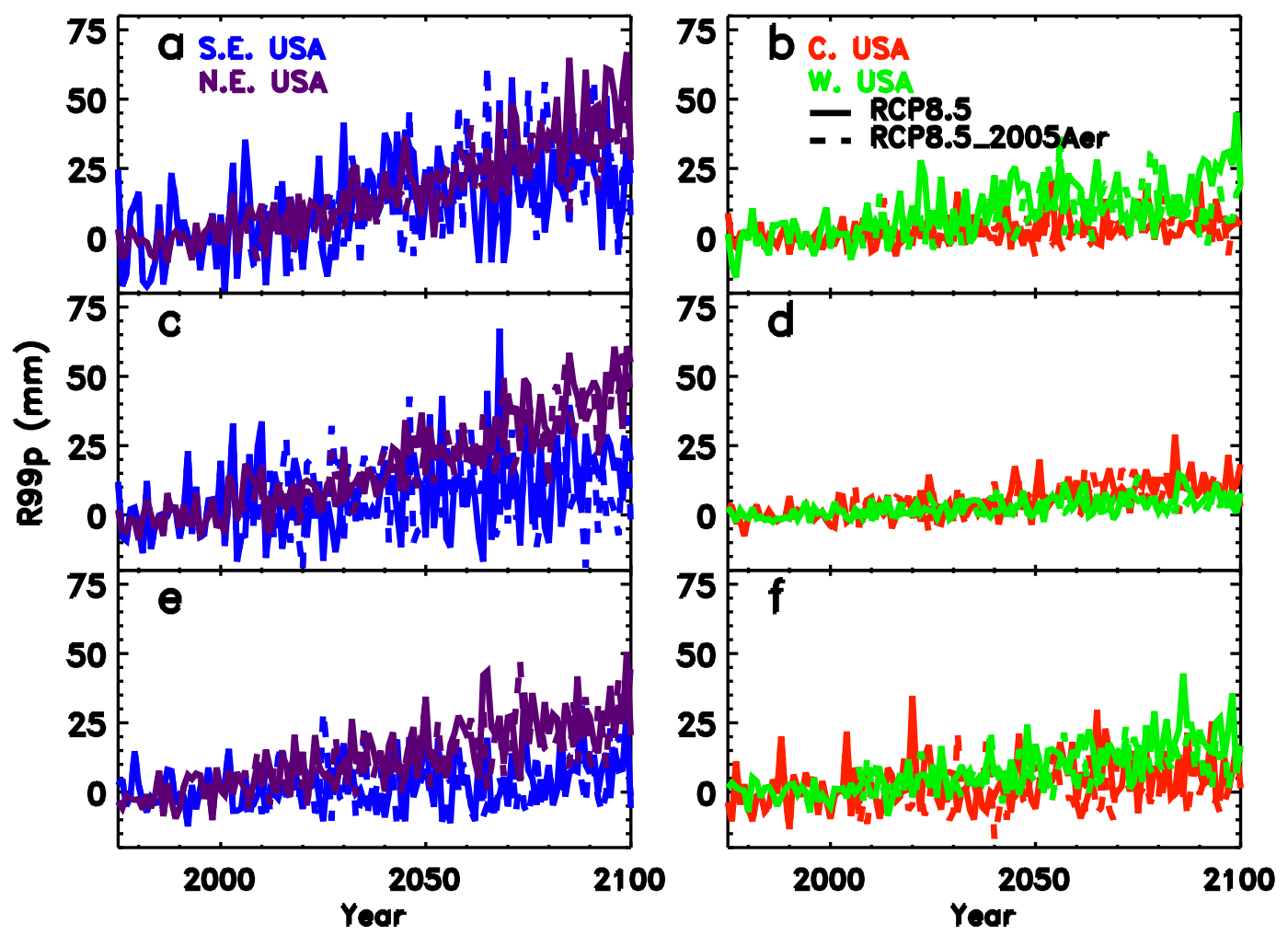

FIG. 7. (a),(b) Winter, (c),(d) spring, and (e),(f) fall R99p for RCP8.5 (solid lines) and RCP8.5_2005Aer (dashed lines) for different U.S. regions, expressed as anomalies with respect to 1976-2005.

by 2050; and in autumn, the signal emerges late in the twenty-first century in the Midwest and Pacific Northwest (Fig. S8b in the supplemental material). The impacts of reductions in aerosol concentrations on extreme precipitation are minimal over the twenty-first century (Fig. 7), and changes in the time of emergence are small (Figs. 8c,d and S8).

\section{Conclusions}

We use the ETCCDI extreme climate indices as a metric for investigating changes in extreme temperature and precipitation in the United States. High temperature extremes in the United States generally decrease in response to aerosols and increase in response to greenhouse gases. We identify clear regional patterns of response to forcing: the western United States has the strongest response to both aerosols and greenhouse gases, while the weakest response occurs in the Southeast (Fig. 3). This compares well with observations of temperature trends in the United States, and lends confidence to the model representation of spatial patterns of temperature extremes, despite the excessively strong aerosol indirect effects (Meehl et al. 2012; Sheffield et al. 2013; Golaz et al. 2013).
Overall, simulated precipitation changes during the historical period concentrate in the eastern and central United States, the regions where the model best captures the observed patterns of the present-day precipitation climatology (Sheffield et al. 2013). In the CM3 model, aerosols tend to reduce extreme precipitation, while greenhouse gases tend to increase it, particularly in the spring (Fig. 4). Although changes in the historical simulation are not significantly different from zero, we note that in the GHG simulation there are large increases in R99p in the Midwest, particularly in spring. This coincides with observed statistically significant increases in extreme precipitation in the Midwest in spring, suggesting that the observed trend may be attributable to greenhouse gases (Kunkel et al. 2008).

The signal associated with greenhouse gases emerges clearly by the end of the twenty-first century for all indices in the extreme warming scenario, RCP8.5, although because of the strength of the aerosol effects in CM3 it is likely that extreme temperature (over the continental United States) and precipitation (over the eastern United States) increase too rapidly in the first half of the twenty-first century. As a result of the combined effects of increasing greenhouse gas concentrations and decreasing aerosol emissions (but primarily 

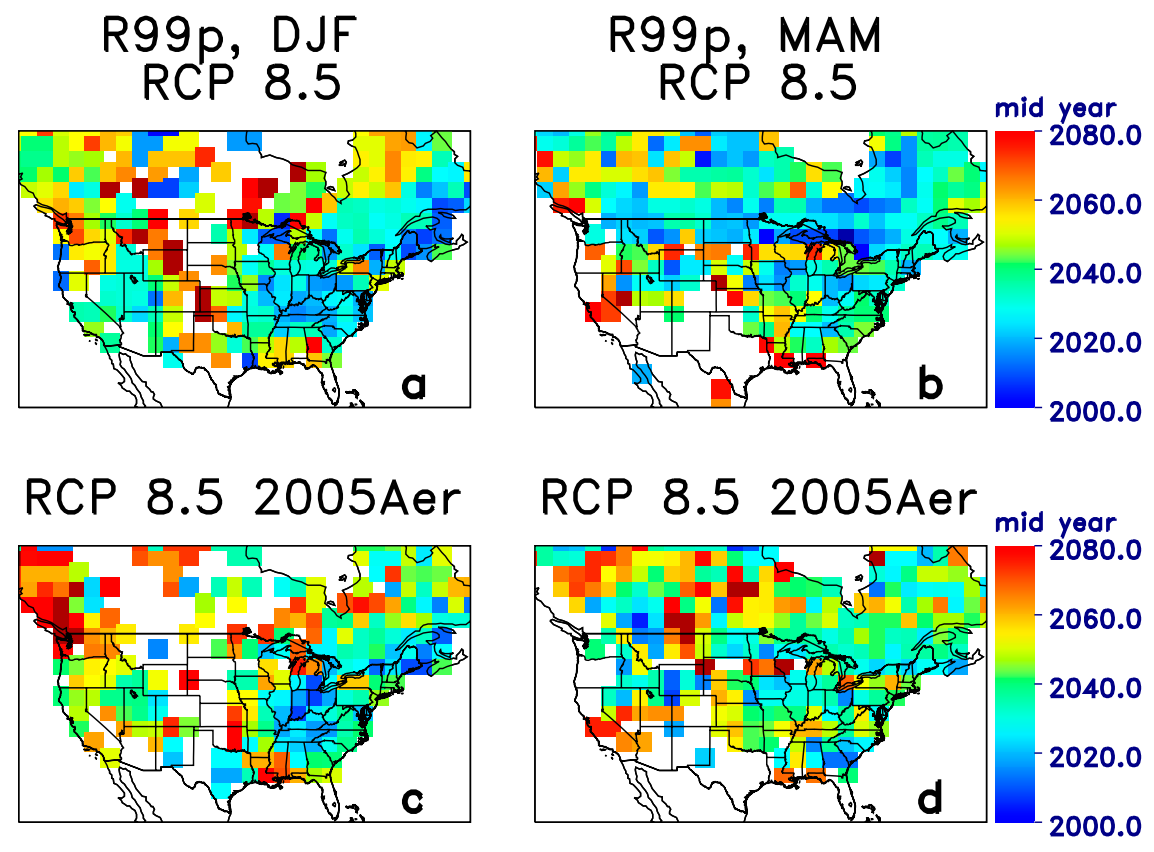

FIG. 8. Time of emergence for changes in 30-yr mean R99p for (a),(c) winter and (b),(d) spring relative to the present day (1976-2005) for the (top) RCP8.5 and (bottom) RCP8.5 2005Aer scenarios. White areas over the continent denote regions where the signal does not emerge over the twenty-first century.

the former), by the end of the century the entire summer lies above the 90th percentile of daily maximum temperature from 1961 to 1990. Seasonal extreme precipitation in winter and spring in the northeastern and central United States increases by up to $40 \mathrm{~mm}$. In fall, extreme precipitation increases in the Northeast and the Northwest despite a lack of significant changes in total precipitation, indicating a change in the shape of the precipitation distribution. Total summertime precipitation increases in the Southeast, although there are no significant changes in extreme precipitation in that region.

Extreme events have major impacts on human health and economics. To predict future changes in these damaging events, we need to improve our understanding of how extreme temperature and precipitation respond to different types of anthropogenic forcing. In the GFDL CM3 model, there are no statistically significant changes in these extremes in the full historical simulation during 1860-2005. However, using single-forcing simulations for the same time period, we find that anthropogenic aerosols and greenhouse gases individually have significant impacts on extremes. The cancellation between the effects of aerosols and greenhouse gases results in the absence of statistically significant changes in the historical simulations, although it is likely that this masking by aerosols is too strong in the model. In the future, as aerosol emissions decrease and greenhouse gas concentrations continue to increase, the impacts of anthropogenic climate change on extreme weather in the United States will emerge.

Acknowledgments. We thank our reviewers for their helpful feedback on this study and our colleague Mingfang Ting for her input throughout the course of this research. This article was made possible by EPA-STAR Grant 83520601 . Its contents are solely the responsibility of the grantee and do not necessarily represent the official view of the EPA. Further, the EPA does not endorse the purchase of any commercial products or services mentioned in the publication.

\section{REFERENCES}

Ackerman, A. S., M. P. Kirkpatrick, D. E. Stevens, and O. B. Toon, 2004: The impact of humidity above stratiform clouds on indirect aerosol climate forcing. Nature, 432, 1014-1017, doi:10.1038/nature03174.

Albrecht, B. A., 1989: Aerosols, cloud microphysics, and fractional cloudiness. Science, 245, 1227-1230, doi:10.1126/ science.245.4923.1227.

Anderson, G. B., and M. L. Bell, 2011: Heat waves in the United States: Mortality risk during heat waves and effect modification by heat wave characteristics in 43 U.S. communities. Environ. Health Perspect., 119, 210-218, doi:10.1289/ ehp.1002313. 
Boucher, O., and Coauthors, 2013: Clouds and aerosols. Climate Change 2013: The Physical Science Basis, T. F. Stocker et al., Eds., Cambridge University Press, 571-658, doi:10.1017/ CBO9781107415324.016.

Changnon, S. A., K. E. Kunkel, and B. C. Reinke, 1996: Impacts and response to the 1995 heat wave: A call to action. Bull. Amer. Meteor. Soc., 77, 1497-1506, doi:10.1175/ 1520-0477(1996)077<1497:IARTTH>2.0.CO;2.

Chin, M., and Coauthors, 2002: Tropospheric aerosol optical thickness from the GOCART model and comparisons with satellite and sun photometer measurements. J. Atmos. Sci., 59, 461-483, doi:10.1175/1520-0469(2002)059<0461: TAOTFT $>2.0 . C O ; 2$.

Curriero, F. C., J. A. Patz, J. B. Rose, and S. Lele, 2001: The association between extreme precipitations and waterborne disease outbreaks in the United States, 1948-1994. Amer. J. Public Health, 91, 1194-1199, doi:10.2105/AJPH.91.8.1194.

Dentener, F., and Coauthors, 2006: Emissions of primary aerosol and precursor gases in the years 2000 and 1750 prescribed data-sets for AeroCom. Atmos. Chem. Phys., 6, 4321-4344, doi:10.5194/acp-6-4321-2006.

Donat, M. G., and Coauthors, 2013a: Updated analyses of temperature and precipitation extreme indices since the beginning of the twentieth century: The HadEX2 dataset. J. Geophys. Res. Atmos., 118, 2098-2118, doi:10.1002/jgrd.50150.

- , and Coauthors, 2013b: The HadEX2 dataset. Met Office Hadley Centre, accessed 24 November 2015. [Available online at http://www.metoffice.gov.uk/hadobs/hadex2/.]

Donner, L. J., and Coauthors, 2011: The dynamical core, physical parameterizations, and basic simulation characteristics of the atmospheric component AM3 of the GFDL global coupled model CM3. J. Climate, 24, 3484-3519, doi:10.1175/ 2011JCLI3955.1.

Engelthaler, D. M., and Coauthors, 1999: Climatic and environmental patterns associated with hantavirus pulmonary syndrome, Four Corners region, United States. Emerg. Infect. Dis., 5, 87-94, doi:10.3201/eid0501.990110.

Ginoux, P., M. Chin, I. Tegen, J. M. Prospero, B. Holben, O. Dubovik, and S.-J. Lin, 2001: Sources and distributions of dust aerosols simulated with the GOCART model. J. Geophys. Res., 106, 22 255-22 274, doi:10.1029/2000JD000053.

Glass, G. E., and Coauthors, 2000: Using remotely sensed data to identify areas of risk for hantavirus pulmonary syndrome. Emerg. Infect. Dis., 6, 238-247, doi:10.3201/eid0603.000303.

Golaz, J.-C., L. W. Horowitz, and H. Levy II, 2013: Cloud tuning in a coupled climate model: Impact on 20th century warming. Geophys. Res. Lett., 40, 2246-2251, doi:10.1002/grl.50232.

Groisman, P. Ya., R. W. Knight, T. R. Karl, D. R. Easterling, B. Sun, and J. H. Lawrimore, 2004: Contemporary changes of the hydrological cycle over the contiguous United States: Trends derived from in situ observations. J. Hydrometeor., 5, 64-85, doi:10.1175/1525-7541(2004)005<0064:CCOTHC >2.0.CO;2.

,,-- D. R. Easterling, T. R. Karl, G. C. Hegerl, and V. N. Razuvaev, 2005: Trends in intense precipitation in the climate record. J. Climate, 18, 1326-1350, doi:10.1175/JCLI3339.1.

Guo, H., J.-C. Golaz, and L. J. Donner, 2011: Aerosol effects on stratocumulus water paths in a PDF-based parameterization. Geophys. Res. Lett., 38, L17808, doi:10.1029/ 2011 GL048611.

Han, Q., W. B. Rossow, and A. A. Lacis, 1994: Near-global survey of effective droplet radii in liquid water clouds using ISCCP data. J. Climate, 7, 465-497, doi:10.1175/1520-0442(1994)007<0465: NGSOED $>2.0 . \mathrm{CO} ; 2$.
Hartmann, D. L., and Coauthors, 2013: Observations: Atmosphere and surface. Climate Change 2013: The Physical Science Basis, T. F. Stocker et al., Eds., Cambridge University Press, 571658, doi:10.1017/CBO9781107415324.016.

Horowitz, L. W., 2006: Past, present, and future concentrations of tropospheric ozone and aerosols: Methodology, ozone evaluation, and sensitivity to aerosol wet removal. J. Geophys. Res., 111, D22211, doi:10.1029/2005JD006937.

Huffman, G. J., R. F. Adler, M. M. Morrissey, S. Curtis, R. Joyce, B. McGavock, and J. Susskind, 2001: Global precipitation at one-degree daily resolution from multi-satellite observations. J. Hydrometeor., 2, 36-50, doi:10.1175/1525-7541(2001)002<0036: GPAODD $>2.0 . \mathrm{CO} ; 2$.

—, D. T. Bolvin, and R. F. Adler, 2015: GPCP Version 1.2 1-Degree Daily (1DD) precipitation data set. WDC-A, NCDC, accessed 22 July 2015. [Available online at ftp://meso.gsfc. nasa.gov/pub/1dd-v1.2.]

Karl, T. R., and R. W. Knight, 1998: Secular trends of precipitation amount, frequency, and intensity in the U.S.A. Bull. Amer. Meteor. Soc., 79, 231-241, doi:10.1175/1520-0477(1998)079<0231: STOPAF $>2.0 . \mathrm{CO} ; 2$.

Kloster, S., F. Dentener, J. Feichter, F. Raes, E. Roeckner, U. Lohmann, and I. Fischer-Bruns, 2010: A GCM study of future climate response to air pollution reduction. Climate Dyn., 34, 1177-1194, doi:10.1007/s00382-009-0573-0.

Kumar, S., J. Kinter III, P. A. Dirmeyer, Z. Pan, and J. Adams, 2013: Multidecadal climate variability and the "warming hole" in North America: Results from CMIP5 twentieth- and twenty-first-century climate simulations. J. Climate, 26, 35113527, doi:10.1175/JCLI-D-12-00535.1.

Kunkel, K. E., and Coauthors, 2008: Observed changes in weather and climate extremes. Weather and climate extremes in a changing climate-Regions of focus: North America, Hawaii, Caribbean, and U.S. Pacific Islands. T. R. Karl et al., Eds., U.S. Climate Change Science Program, 35-79. [Available online at https://www.agci.org/lib/07s1/weather-and-climate-extremeschanging-climate? recordID $=17228$.]

_- and Coauthors, 2013: Monitoring and understanding trends in extreme storms: State of knowledge. Bull. Amer. Meteor. Soc., 94, 499-514, doi:10.1175/BAMS-D-11-00262.1.

Lamarque, J.-F., and Coauthors, 2010: Historical (1850-2000) gridded anthropogenic and biomass burning emissions of reactive gases and aerosols: Methodology and application. Atmos. Chem. Phys., 10, 7017-7039, doi:10.5194/ acp-10-7017-2010.

Lau, N.-C., and M. J. Nath, 2012: A model study of heat waves over North America: Meteorological aspects and projections for the 21st century. J. Climate, 25, 4761-4784, doi:10.1175/ JCLI-D-11-00575.1.

Leibensperger, E. M., and Coauthors, 2012: Climatic effects of 1950-2050 changes in US anthropogenic aerosols-Part 2: Climate response. Atmos. Chem. Phys., 12, 3349-3362, doi:10.5194/acp-12-3349-2012.

Leung, R. L., and W. I. Gustafson Jr., 2005: Potential regional climate change and implications to US air quality. Geophys. Res. Lett., 32, L16711, doi:10.1029/2005GL022911.

Levy, H., L. W. Horowitz, M. D. Schwarzkopf, Y. Ming, J.-C. Golaz, V. Naik, and V. Ramaswamy, 2013: The roles of aerosol direct and indirect effects in past and future climate change. J. Geophys. Res. Atmos., 118, 4521-4532, doi:10.1002/ jgrd.50192.

Logan, J. A., 1989: Ozone in rural areas of the United States. J. Geophys. Res., 94, 8511-8532, doi:10.1029/JD094iD06p08511. 
Lott, N., and T. Ross, 2006: Tracking and evaluating U.S. billion dollar weather disasters, 1980-2005. Proc. Forum on Environmental Risk and Impacts on Society: Successes and Challenges, Atlanta, GA, Amer. Meteor. Soc., 1.2. [Available online at http://ams.confex.com/ams/pdfpapers/100686.pdf.]

Maloney, E. D., and Coauthors, 2014: North American climate in CMIP5 experiments: Part III: Assessment of twenty-firstcentury projections. J. Climate, 27, 2230-2270, doi:10.1175/ JCLI-D-13-00273.1.

Meehl, G., J. Arblaster, and G. Branstator, 2012: Mechanisms contributing to the warming hole and the consequent U.S east-west differential of heat extremes. J. Climate, 25, 63946408, doi:10.1175/JCLI-D-11-00655.1.

Ming, Y., V. Ramaswamy, L. Donner, and V. T. J. Phillips, 2006: A new parameterization of cloud droplet activation applicable to general circulation models. J. Atmos. Sci., 63, 1348-1356, doi:10.1175/JAS3686.1.

$-,-\longrightarrow,-$, S. A. Klein, P. A. Ginoux, and L. W. Horowitz, 2007: Modeling the interactions between aerosols and liquid water clouds with a self-consistent cloud scheme in a general circulation model. J. Atmos. Sci., 64, 1189-1209, doi:10.1175/JAS3874.1.

Misra, V., J.-P. Michael, R. Boyles, E. P. Chassignet, M. Griffin, and J. J. O'Brien, 2012: Reconciling the spatial distribution of the surface temperature trends in the southeastern United States. J. Climate, 25, 3610-3618, doi:10.1175/JCLI-D-11-00170.1.

Monahan, E. C., D. E. Spiel, and K. L. Davidson, 1986: A model of marine aerosol generation via whitecaps and wave disruption. Oceanic Whitecaps, E. C. Monahan and G. Mac Niocaill, Eds., D. Reidel, 167-174.

Naik, V., L. W. Horowitz, A. M. Fiore, P. Ginoux, J. Mao, A. M. Aghedo, and H. Levy II, 2013: Impact of preindustrial to present-day changes in short-lived pollutant emissions on atmospheric composition and climate forcing. J. Geophys. Res. Atmos., 118, 8086-8110, doi:10.1002/jgrd.50608.

O'Dowd, C. D., B. Langmann, S. Varghese, C. Scannell, D. Ceburnis, and M. C. Facchini, 2008: A combined organicinorganic sea spray source function. Geophys. Res. Lett., 35 , L01801, doi:10.1029/2007GL030331.

Pan, Z., R. W. Arritt, E. S. Takle, W. J. Gutowski Jr., C. J. Anderson, and M. Segal, 2004: Altered hydrologic feedback in a warming climate introduces a "warming hole." Geophys. Res. Lett., 31, L17109, doi:10.1029/2004GL020528.

_ - X. Liu, S. Kumar, Z. Gao, and J. Kinter, 2013: Intermodel variability and mechanism attribution of central and southeastern U.S. anomalous cooling in the twentieth century as simulated by CMIP5 models. J. Climate, 26, 6215-6237, doi:10.1175/JCLI-D-12-00559.1.

Peterson, T. C., X. Zhang, M. Brunet-India, and J. L. VázquezAguirre, 2008: Changes in North American extremes derived from daily weather data. J. Geophys. Res., 113, D07113, doi:10.1029/2007JD009453.

Portmann, R. W., S. Solomon, and G. C. Hegerl, 2009: Spatial and seasonal patterns in climate change, temperatures, and precipitation across the United States. Proc. Natl. Acad. Sci. USA, 106, 7324-7329, doi:10.1073/pnas.0808533106.

Quaas, J., and Coauthors, 2009: Aerosol indirect effects-General circulation model intercomparison and evaluation with satellite data. Atmos. Chem. Phys., 9, 8697-8717, doi:10.5194/ acp-9-8697-2009.

Riahi, K., and Coauthors, 2011: RCP8.5-A scenario of comparatively high greenhouse gas emissions. Climatic Change, 109, 33-57, doi:10.1007/s10584-011-0149-y.

Sheffield, J., and Coauthors, 2013: North American climate in CMIP5 experiments. Part I: Evaluation of historical simulations of continental and regional climatology. J. Climate, 26, 92099245, doi:10.1175/JCLI-D-12-00592.1.

Shindell, D. T., A. Voulgarakis, G. Faluvegi, and G. Milly, 2012: Precipitation response to regional radiative forcing. Atmos. Chem. Phys., 12, 6969-6982, doi:10.5194/acp-12-6969-2012.

Sillmann, J., V. V. Kharin, X. Zhang, F. W. Zwiers, and D. Bronaugh, 2013a: Climate extremes indices in the CMIP5 multimodel ensemble: Part 1. Model evaluation in the present climate. J. Geophys. Res. Atmos., 118, 1716-1733, doi:10.1002/ jgrd.50203.

, — , F. W. Zwiers, X. Zhang, and D. Bronaugh, 2013b: Climate extremes indices in the CMIP5 multimodel ensemble: Part 2. Future climate projections. J. Geophys. Res. Atmos., 118, 2473-2493, doi:10.1002/jgrd.50188.

Tai, A. P. K., L. J. Mickley, and D. J. Jacob, 2010: Correlations between fine particulate matter (PM 2.5) and meteorological variables in the United States: Implications for the sensitivity of PM2.5 to climate change. Atmos. Environ., 44, 3976-3984, doi:10.1016/j.atmosenv.2010.06.060.

$\longrightarrow,-, \ldots$, E. M. Leibensperger, L. Zhang, J. A. Fisher, and H. O. T. Pye, 2012: Meteorological modes of variability for fine particulate matter $\left(\mathrm{PM}_{2.5}\right)$ air quality in the United States: Implications for $\mathrm{PM}_{2.5}$ sensitivity to climate change. Atmos. Chem. Phys., 12, 3131-3145, doi:10.5194/acp-12-3131-2012.

Taylor, K. E., R. J. Stouffer, and G. A. Meehl, 2012: An overview of CMIP5 and the experiment design. Bull. Amer. Meteor. Soc., 93, 485-498, doi:10.1175/BAMS-D-11-00094.1.

Tie, X., and Coauthors, 2005: Assessment of the global impact of aerosols on tropospheric oxidants. J. Geophys. Res., 110, D03204, doi:10.1029/2004JD005359.

TRMM Project, 2015: Daily TRMM and others rainfall estimate (3B42 V7 derived), version 7. GSFC DAAC, accessed 23 July 2015. [Available online at http://mirador.gsfc.nasa.gov/collections/ TRMM_3B42_daily_007.shtml.]

Twomey, S., 1977: The influence of pollution on the shortwave albedo of clouds. J. Atmos. Sci., 34, 1149-1152, doi:10.1175/ 1520-0469(1977)034<1149:TIOPOT>2.0.CO;2.

van Vuuren, D. P., and Coauthors, 2011: The representative concentration pathways: An overview. Climatic Change, 109, 5-31, doi:10.1007/s10584-011-0148-z.

Weaver, S., 2013: Factors associated with decadal variability in Great Plains summertime surface temperatures. J. Climate, 26, 343-350, doi:10.1175/JCLI-D-11-00713.1.

Westervelt, D. M., L. W. Horowitz, V. Naik, and D. L. Mauzerall, 2015: Radiative forcing and climate response to projected 21st century aerosol decreases. Atmos. Chem. Phys., 15, $12681-$ 12 703, doi:10.5194/acpd-15-9293-2015.

Yu, S., and Coauthors, 2014: Attribution of the United States "warming hole": Aerosol indirect effect and precipitable water vapor. Sci. Rep., 4, 6929, doi:10.1038/srep06929. 